\title{
Language barriers in medical education and attitudes towards Arabization of medicine: student and staff perspectives
}

\author{
S.M. Sabbour, ${ }^{\text {S.A. Dewedar }}{ }^{1}$ and S.K. Kandil ${ }^{1}$
}

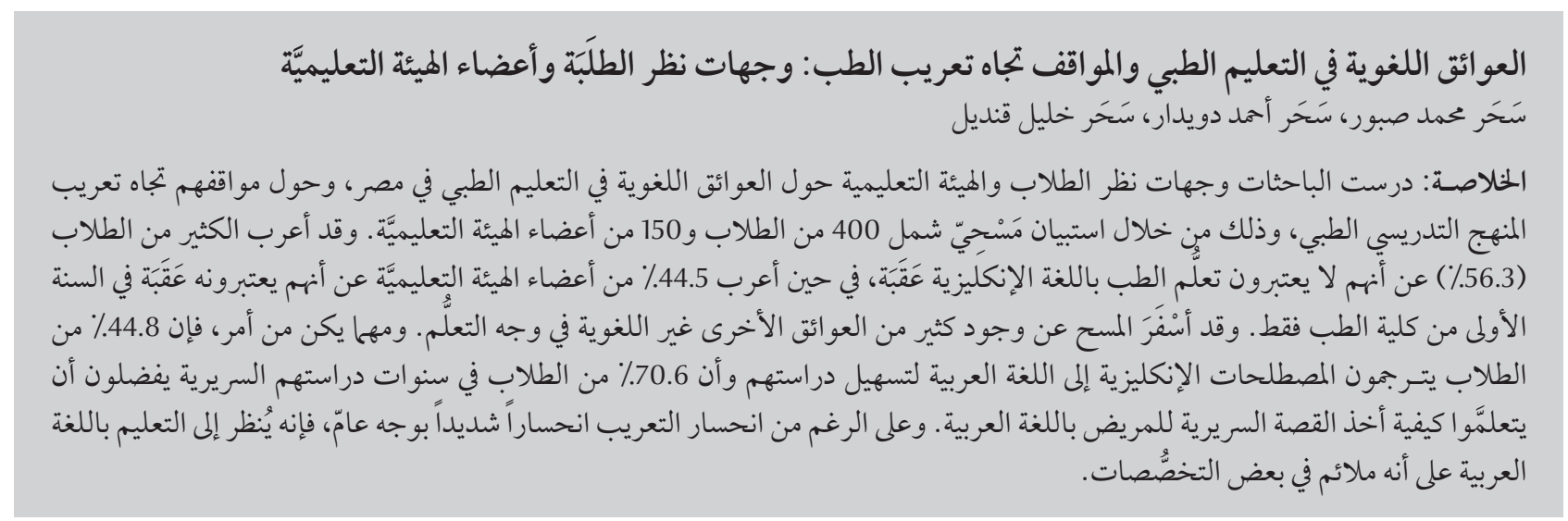

ABSTRACT Students and staff perspectives on language barriers in medical education in Egypt and their attitude towards Arabization of the medical curriculum were explored in a questionnaire survey of 400 medical students and 150 staff members. Many students (56.3\%) did not consider learning medicine in English an obstacle, and $44.5 \%$ of staff considered it an obstacle only in the 1st year of medical school. Many other barriers to learning other than language were mentioned. However, $44.8 \%$ of students translated English terms to Arabic to facilitate studying and $70.6 \%$ of students in their clinical study years would prefer to learn patient history-taking in Arabic. While Arabization in general was strongly declined, teaching in Arabic language was suggested as appropriate in some specialties.

Les barrières linguistiques dans l'enseignement médical et l'état d'esprit concernant l'arabisation de la médecine : le point de vue des étudiants et du personnel médical

RÉSUMÉ Dans une enquête par questionnaire, le point de vue de 400 étudiants en médecine et de 150 membres du personnel médical sur les barrières linguistiques dans l'enseignement médical en Égypte et leur opinion concernant l'arabisation du cursus médical ont été étudiés. De nombreux étudiants (56,3\%) ne considéraient pas l'apprentissage de la médecine en langue anglaise comme un obstacle, alors que 44,5\% du personnel médical percevaient cette pratique comme une difficulté uniquement pendant la première année d'études à la faculté de médecine. De nombreux obstacles à l'apprentissage de la médecine, autres que la barrière linguistique, ont été mentionnés. Toutefois, 44,8 \% des étudiants traduisaient les termes anglais en arabe pour faciliter leur apprentissage et 70,6 \% des étudiants auraient préféré apprendre à noter les antécédents des patients en langue arabe. Si l'idée de l'arabisation était fortement rejetée de manière générale, en revanche, l'enseignement dans cette langue était perçu comme approprié pour certaines spécialités. 


\section{Introduction}

English has spread as the teaching language in the Arab world in many fields of higher education, prompting debate about the advantages and disadvantages of studying in English. The arguments in favour of teaching medicine in a student's mother tongue have been stated before $[1-5]$. The use of the mother language in teaching medicine is seen as a way to free learners from the linguistic dualism imposed by thinking in one language and studying in another [6].

Many Arab countries teach medicine entirely in English (or French), others have certain medical subjects taught in Arabic, while in Syria all courses are taught in Arabic [5]. The rationale for continuing to teach medicine in English focuses on the fact that much of the scientific, technological and academic information in the world is expressed in English [7] and that medical students or doctors attending international conferences, courses or clerkships abroad need to be proficient in the English language [8]. However, in 2005, the Arabization Center for Medical Science (ACMLS), together with the deans of medical schools in the Arab world, argued that learning medicine in Arabic does not hinder doctors from completing their education abroad or from staying up-to-date with medical advances worldwide [9]. The concept of medical Arabization does not mean abandoning English altogether; rather the aim is for the students to learn better in their native language while maintaining a good knowledge of English as the leading language of medical research today, as is the case in Japan, Germany, France, Scandinavia and some other European countries [6].

These different views are prompting medical educators to explore and identify learning difficulties related to language. Previous studies have addressed the problem of English language for Arab medical students [10]. In Egypt elementary school education is mainly in Arabic, and while some students become proficient in English, others may experience difficulties with language when they progress to higher education. Yet, in the context of rapid globalization, there are concerns about accreditation of medical schools, including student qualifications, residency training and continuing education [11].

The Faculty of Medicine at Ain Shams University is one of the leading medical faculties in Egypt and is progressing towards international accreditation. In order to provide language education support, it is essential that students' learning needs are assessed and that useful feedback and advice are provided. The aim of the present study was to explore the language barriers encountered by students in some aspects of their medical education, such as studying from books, in lectures and in examinations, and to determine the attitude of medical students and Faculty staff towards the Arabization of the medical curriculum.

\section{Methods}

The study was conducted in the Faculty of Medicine, Ain Shams University, Cairo, Egypt at the beginning of the academic year 2008. It was designed as an anonymous questionnaire survey to staff and students.

\section{Study tools}

Two questionnaire forms ( 1 for students, 1 for staff) were designed in Arabic. These explored language problems, obstacles to the medical education process and attitudes towards Arabization. Besides personal data, the questionnaire enquired about 3 aspects of language problems: university textbooks, lectures (academic and clinical) and examinations. We also explored barriers due to the language of instruction in the context of other issues in the medical education process in order to identify its actual weight relative to other obstacles. The questionnaires included a section on the consequences and expectations about the Arabization of medical education from the perspectives of both students and staff. Response to questions were dichotomous (yes/no, agree/disagree) or a Likert-type scale (attitudes towards Arabization). Two open-ended questions were used for other comments or suggestions.

\section{Subjects}

This study included 326 medical students and 110 faculty staff members. Staff members were enrolled from different departments to get a broad view. This was achieved through distributing questionnaires to all attendees during the preparatory meetings organized by the Faculty of Medicine for the work plan needed for accreditation. Other staff members were surveyed at the examination hall where the written exams are corrected. The Dean and vice-deans of the Faculty were contacted at their offices. Questionnaires were distributed to students, without regard to grade or sex, during the Faculty orientation day for accreditation of Ain Shams Medical School held on 18 February 2008. All learning activities were cancelled on that day to allow many students to attend. We also distributed questionnaires in later meetings with students.

\section{Ethical considerations}

Ain Shams University Faculty of Medicine research ethics committee approved the protocol for this study. The questionnaires were anonymous and when they were distributed it was emphasized that participation was voluntary.

\section{Statistical analysis}

SPSS, version 13 was used for analysing the results. Simple frequency analysis was used to describe demographics and opinions. Percentages were calculated for each question from those who answered. The chi-squared test was used to test for associations. 


\section{Results}

\section{Background characteristics of sample}

The response rate was $81.5 \%(326 / 400)$ among students and $73.3 \%(110 / 150)$ among staff members.

Three-quarters $(74.9 \%)$ of the students had graduated from schools where Arabic was the first language; only $15.8 \%$ had studied at English language schools (Table 1). Of the staff members recruited in the study, $19.4 \%$ had leading positions in the faculty.

\section{Problems in medical education}

The major problem in medical education as a whole reported by a majority of students (61.9\%) was the high (and increasing) numbers of students in class (Table 2). Moderate problems were identified as: the tutors, content of the curriculum and teaching and assessment methods. Teaching medicine in a foreign language (English) was not viewed as a problem by $56.3 \%$ of students.

\section{Problems with English language}

Of the faculty staff $35.8 \%$ agreed that a gap was caused by the difference between the language of instruction in medical teaching and the actual practice of medicine, and a similar proportion agreed that teaching in the mother tongue was more appropriate for students to create a harmony between thinking and speaking (data not tabulated).

While $44.5 \%$ of staff members considered that teaching medicine in English was a barrier for students in the 1st year only, $12.8 \%$ considered it not to be a problem at all (Figure 1). Only 3 staff members $(2.7 \%)$ believed that it was a barrier to the learning process.

As for the $139 / 318$ students (43.7\%) who mentioned that the English language was a major/moderate problem in their medical education,

\begin{tabular}{|c|c|c|}
\hline Item & No. & $\%$ \\
\hline \multicolumn{3}{|c|}{ Medical students } \\
\hline \multicolumn{3}{|l|}{$\operatorname{Sex}(n=326)$} \\
\hline Male & 124 & 38.0 \\
\hline Female & 202 & 62.0 \\
\hline \multicolumn{3}{|l|}{ Grade $(n=326)$} \\
\hline 1st year & 102 & 31.3 \\
\hline 2nd year & 27 & 8.3 \\
\hline 3rd year & 10 & 3.1 \\
\hline 4th year & 88 & 27.0 \\
\hline 5 th year & 43 & 13.2 \\
\hline 6 th year & 56 & 17.2 \\
\hline \multicolumn{3}{|l|}{ School type \& language of tuition $(n=323)^{a}$} \\
\hline Private school, English language & 51 & 15.8 \\
\hline $\begin{array}{l}\text { Government experimental school, } \\
\text { English language }\end{array}$ & 30 & 9.3 \\
\hline Government school, Arabic language & 242 & 74.9 \\
\hline \multicolumn{3}{|l|}{ Type of school certificate $(n=324)^{a}$} \\
\hline General secondary certificate & 304 & 93.8 \\
\hline Other & 20 & 6.2 \\
\hline \multicolumn{3}{|c|}{ Faculty staff } \\
\hline \multicolumn{3}{|l|}{$\operatorname{Sex}(n=110)$} \\
\hline Male & 39 & 35.5 \\
\hline Female & 71 & 64.5 \\
\hline \multicolumn{3}{|l|}{ Academic degree $(n=110)$} \\
\hline Assistant lecturer & 12 & 10.9 \\
\hline Lecturer & 19 & 17.3 \\
\hline Assistant professor & 25 & 22.7 \\
\hline Professor & 54 & 49.1 \\
\hline \multicolumn{3}{|l|}{ Department $(n=98)^{a}$} \\
\hline Clinical & 31 & 31.0 \\
\hline Academic & 69 & 69.0 \\
\hline \multicolumn{3}{|l|}{ Leadership position $(n=110)$} \\
\hline Yes & 22 & 19.4 \\
\hline No & 88 & 80.6 \\
\hline
\end{tabular}

${ }^{a}$ Missing data.

1 st year (26.3\%) and 2nd year (22.2\%) students complained more than those in the other years (17.8\%)

When they were asked whether they found any difficulty in lectures, university textbooks, oral or written exams and patient communication due to being taught in English, 160 (49.1\%) students reported difficulty in patient communication and $124(38.0 \%)$ in the oral exams (data not tabulated).

\section{Language barriers}

We enquired about language barriers in the context of other defects in the current university textbooks (produced by the university staff) (Figure 2) and medical lectures (Figure 3). Obstacles mentioned included books were written in English (13.7\%), had summarized information (14.3\%), contained chapters that were unrelated (49.7\%), used complicated wording and phrases 


\begin{tabular}{|c|c|c|}
\hline Item & No. & $\%$ \\
\hline \multicolumn{3}{|c|}{ Teaching medicine in a foreign language is: } \\
\hline A major problem & 29 & 9.1 \\
\hline A moderate problem & 110 & 34.6 \\
\hline Not a problem & 179 & 56.3 \\
\hline \multicolumn{3}{|c|}{ Content of the curriculum is: } \\
\hline A major problem & 79 & 24.8 \\
\hline A moderate problem & 160 & 50.3 \\
\hline Not a problem & 79 & 24.8 \\
\hline \multicolumn{3}{|l|}{ Teaching methods are: } \\
\hline A major problem & 120 & 37.9 \\
\hline A moderate problem & 150 & 47.3 \\
\hline Not a problem & 47 & 14.8 \\
\hline \multicolumn{3}{|c|}{ Tutors' level (as an educator) is: } \\
\hline A major problem & 93 & 29.6 \\
\hline A moderate problem & 162 & 51.6 \\
\hline Not a problem & 59 & 18.8 \\
\hline \multicolumn{3}{|c|}{ Methods of assessment are: } \\
\hline A major problem & 115 & 37.2 \\
\hline A moderate problem & 133 & 43.0 \\
\hline Not a problem & 61 & 19.7 \\
\hline \multicolumn{3}{|c|}{ High numbers of medical students are: } \\
\hline A major problem & 197 & 61.9 \\
\hline A moderate problem & 82 & 25.8 \\
\hline Not a problem & 39 & 12.3 \\
\hline
\end{tabular}

Major problem $=$ more than $50 \%$ as an obstacle for students in the learning process.

Moderate problem $=$ less than $50 \%$ as an obstacle for students in the learning process.

(56.1\%), were not logically arranged (67.7\%) and had too much unnecessary information (69.8\%).

Students reported finding lectures inefficient as a learning tool due to incompetent tutors $(74.1 \%)$ (the reasons were not probed further) (Figure 3). The least mentioned problem with lectures was English language (18.3\%). In an open-ended question, other lecture defects pointed out by students were the crowdedness of the lecture halls, poor ventilation $(25.5 \%)$, too much information in a short time (22.2\%) and poor use of audiovisual aids (18.0\%).

Regarding details about language difficulties encountered by students in university textbooks, lectures and exams, $73.2 \%$ of students found that the language used in the university books made it difficult for them to obtain studying, while $39.1 \%$ thought that foreign-produced English language textbooks had easier and clearer language than the university books. More than half of students (56.8\%) found difficulty in following the lectures that were totally delivered in English and $31.3 \%$ of students had difficulties with language in the written exam questions.

Around one-third of students (32.0\%) preferred that tutors use only English in lectures while $34.0 \%$ preferred a mixture of Arabic and English in the same lecture. Around $70 \%$ of students agreed that they preferred learning patient history-taking in clinical medicine in Arabic but $70 \%$ also believed that doctors and students should talk in English in front of patients (bedside teaching). Many students (61.8\%) in the years of clinical practice in medicine (4th-6th years) agreed that learning medicine in English created a gap in their dealing with patients (Table 3). Regarding exams, $55.2 \%$ of students preferred to be allowed to answer in Arabic language in written and oral exams.

\section{Language difficulties in exams}

Asked about language difficulties in exams that should been answered only in English, nearly 8\% of students admitted to answering some parts of the written questions in Arabic. Regarding the multiple choice questions exam,

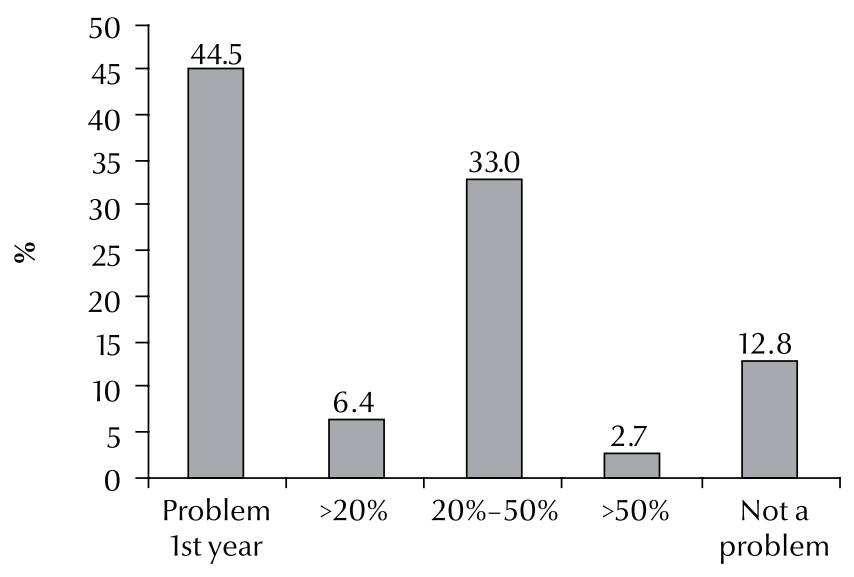

View

Figure 1 Faculty staff views of language barriers for students in their medical education $(n=110)$ 


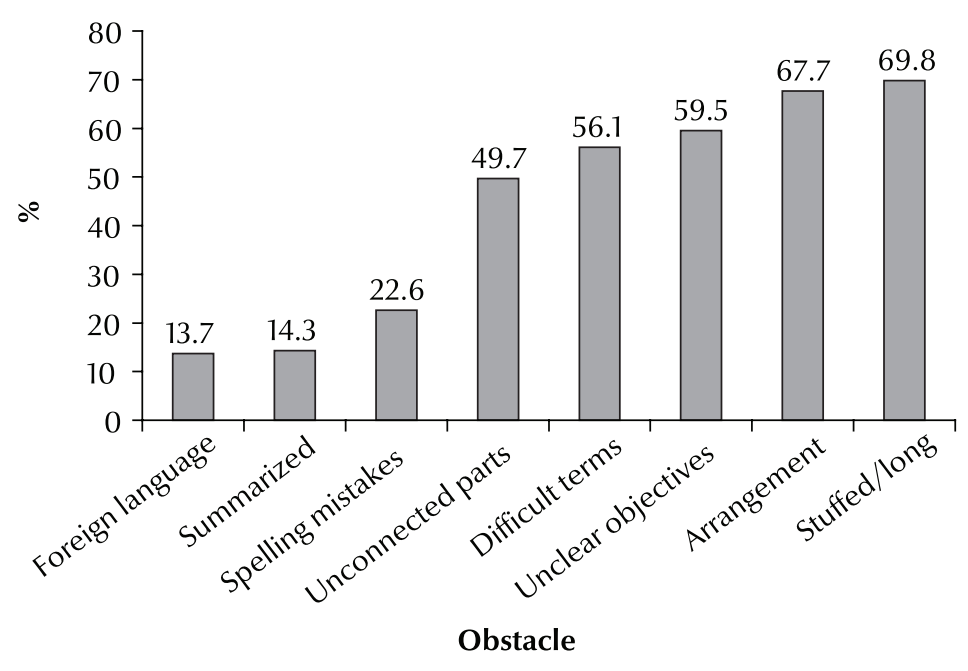

Figure 2 Student views of barriers to learning due to university medical textbooks $(n=326)$

$43.7 \%$ of students had difficulty in understanding the language used in some parts of it. Half the staff (50.9\%) were aware of students' complaints about language difficulties in university medical exams. The majority of staff members (89.9\%) insisted that students must know and use English terminology in their exams.

\section{Expectations and consequences of Arabization of medicine}

The expected consequences of the Arabization of medicine revealed similar responses among students and staff
(Table 4). Most agreed that Arabization would create a new language with difficult Arabic terminology far removed from people's everyday language (this was identified by $80.8 \%$ of students and $74.6 \%$ of staff). Also $60.0 \%$ of staff and $53.9 \%$ of students agreed that Arabization was logical only if we have sufficient translated textbooks. However, more students (40.7\%) than staff members (28.7\%) expected that Arabization would result in a harmony between student's thinking and speaking and hence lead to better performance $(P<0.05)$.

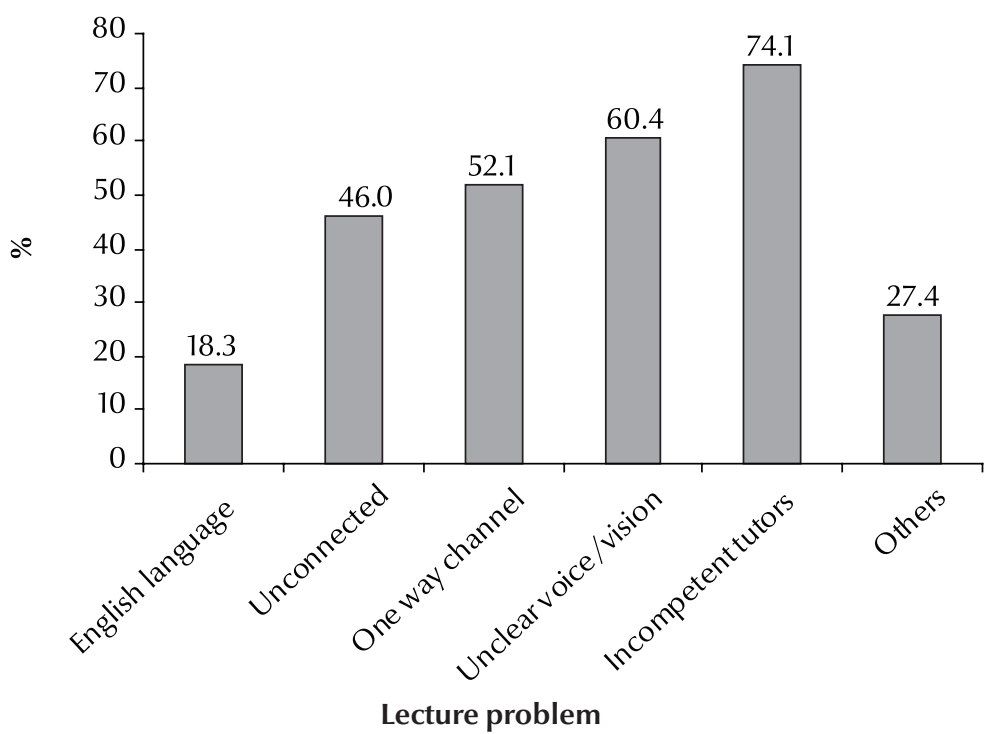

Figure 3 Student views of barriers to learning due to university lectures $(n=326)$

\section{Attitudes towards Arabization of medicine}

Opposition to Arabic teaching of medicine was apparent from both staff and students (Figure 4). At present, 39.1\% of staff and $31.5 \%$ of students were opposed to the idea of Arabization and only $5.5 \%$ of staff and $8.6 \%$ of students strongly agreed with Arabization. The difference between staff and students opinions was not significant $\left(\chi^{2}=5.35\right.$, $P>0.05$ ).

The language used by tutors in lectures, whether purely English or a mixture of Arabic and English, had no relation to their attitude towards Arabization; nearly three-quarters of both groups ( $73.0 \%$ who use English only and $75.5 \%$ who used a mixture) disagreed with Arabization $(P>0.05)$, although $28.6 \%$ of staff members admitted that lectures taught in Arabic would be more easily communicated to students.

Nearly one-third of staff members $(33,30.3 \%)$ and students $(103,31.6 \%)$ agreed that Arabic teaching was needed in some branches of medicine. The main branches suggested were public health and community medicine by 7 (21.2\%) staff and 29 (28.2\%) students, communication skills and health education by $10(30.3 \%)$ staff and 12 (11.6\%) students. Other subjects where it was suggested that Arabic could be used were medical ethics, psychiatry and internal medicine.

Regarding factors affecting staff and students' attitudes towards Arabizing medicine, male staff showed more acceptance for Arabization than female $\operatorname{staff}\left(\chi^{2}=5.78, P=0.05\right)$. No significant difference was found between staff working in leadership positions and others, nor between those in clinical versus academic departments. As for students' attitude, those who had graduated from Arabic language schools and those whose (self-perceived) English level was inadequate showed more acceptance for Arabization $(P<0.01)$. Sex and study year were not significant factors (data not tabulated). 


\begin{tabular}{|c|c|c|}
\hline Lectures & No. & $\%$ \\
\hline \multicolumn{3}{|l|}{$\begin{array}{l}\text { Language used in lecture (in both presentations and } \\
\text { explanations) }(n=294)\end{array}$} \\
\hline Prefer lectures given totally in English & 94 & 32.0 \\
\hline Prefer lectures given in both English and Arabic & 100 & 34.0 \\
\hline Prefer lectures given totally in Arabic & 100 & 34.0 \\
\hline \multicolumn{3}{|l|}{ Clinical rounds } \\
\hline Prefer learning patient history-taking in Arabic & 168 & 69.4 \\
\hline $\begin{array}{l}\text { During bedside teaching doctors and students should } \\
\text { speak in English }\end{array}$ & 178 & 70.6 \\
\hline $\begin{array}{l}\text { Learning medicine in English created a gap in my } \\
\text { dealing with patients }(n=170)^{\text {a }}\end{array}$ & 105 & 61.8 \\
\hline
\end{tabular}

${ }^{a}$ Students in their clinical practice years (4th-6th grades).

\section{Opinions concerning Arabization of medicine}

Through open-ended questions, other opinions and suggestions about Arabizing medicine were raised. The main arguments against Arabization from staff members were that graduates would not be able to compete internationally. They also mentioned that there were other important problems concerning medical education than the language barrier. Suggestions to overcome difficulties with teaching in English were: improving language proficiency in school years before joining college; ensuring that students have access to English textbooks; and supplying students with a medical dictionary of Arabic terminology.

\section{Discussion}

In the present study, students were able to criticize and identify various barriers in the current medical education specific to the language of instruction. Over $50 \%$ of students mentioned that the teaching medicine in a foreign language was not a problem in the learning process. The same applied to the university textbooks and lectures, for which the use of a foreign language was the least drawback. English has been the main teaching language in Egyptian medical schools for many years and most students in our survey did not propose any alternative to the teaching language. However, about $44 \%$ of students mentioned that learning in a foreign language was a problem in understanding the scientific knowledge, while 9\% considered it a major problem.

The students were asked about detailed problems related to university textbooks, lectures and methods of assessment. Only $13.7 \%$ thought that language was one of the problems with university textbooks; however, $56.8 \%$ agreed that they had difficulty in following lectures totally delivered in English and 31.3\% found difficulty in understanding exam questions written in English. These results suggest that teaching in a foreign language actually affects several different aspects of the learning process.

Many staff members (44.5\%) believed that the language barrier that some medical students experienced was just a transient problem in the 1st year of study. They expected that students would overcome it as they advanced in learning. This opinion may be correct as three-quarters of the sample of students in the present study had graduated from Arabic language schools where English was a second language.

Medical students are able to differentiate between effective and ineffective teaching methods in lectures. An earlier study showed that students regarded having lectures by properly qualified teachers as particularly important [12]. In Kuwait, students evaluating the teaching characteristics of their lecturers stated that well-delivered, organized and logical lectures were the most effective [13]. This result of the Kuwait study is consistent with the present study as among the most important problems with lectures for students in our present study were incompetent tutors, disorganized lectures and being a one-way channel without interaction. A study in Saudi Arabia emphasized the importance of good lectures and lecturers in

\begin{tabular}{|c|c|c|c|c|}
\hline \multirow[t]{2}{*}{ Consequences of Arabization of medicine } & \multicolumn{2}{|c|}{$\begin{array}{c}\text { Staff } \\
(n=110)\end{array}$} & \multicolumn{2}{|c|}{$\begin{array}{l}\text { Students } \\
(n=326)\end{array}$} \\
\hline & No. & $\%$ & No. & $\%$ \\
\hline $\begin{array}{l}\text { Arabization will result in a strange language with difficult Arabic } \\
\text { terminology which will be different from patients' everyday language }\end{array}$ & 50 & 74.6 & 227 & 80.8 \\
\hline Arabization can only be applied if translated textbooks are available & 48 & 60.0 & 146 & 53.9 \\
\hline Arabization will create harmony between students' thinking and speaking & 31 & 28.7 & 118 & $40.7^{*}$ \\
\hline Arabization will hinder scientific development and will result in isolation & 79 & 72.5 & 217 & 74.8 \\
\hline Arabization will affect negatively students' medical level & 72 & 66.7 & 173 & 61.1 \\
\hline
\end{tabular}

${ }^{*} P<0.05$ staff versus students. 


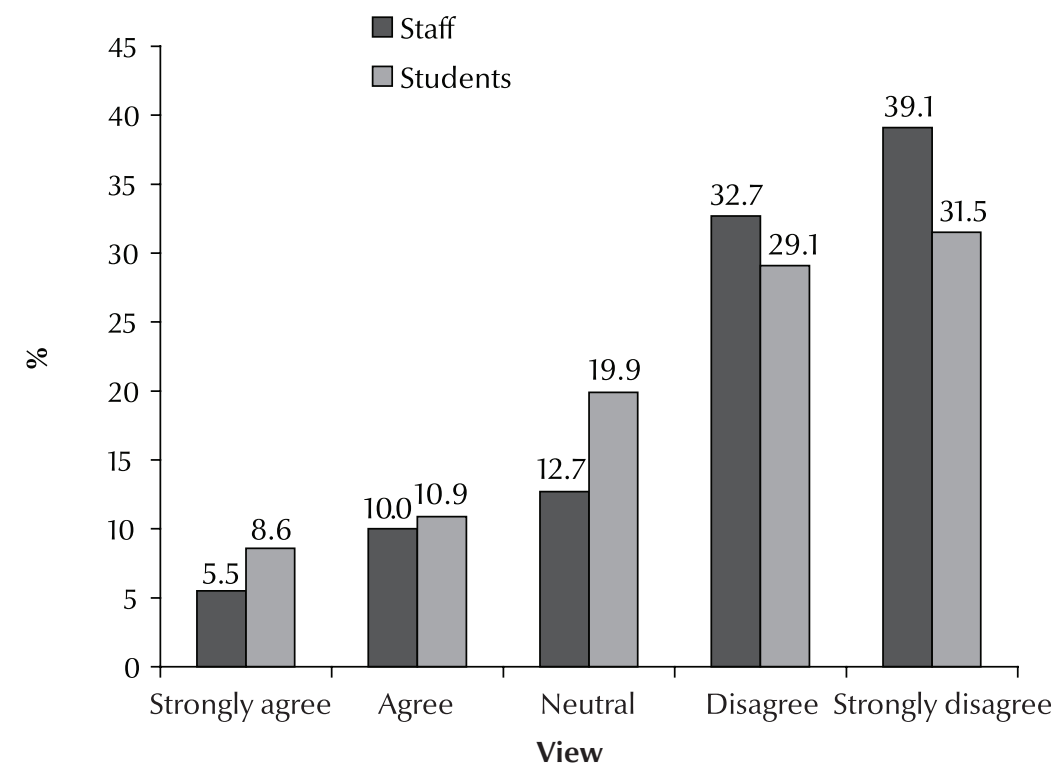

Figure 4 Staff $(n=110)$ and student $(n=326)$ views about Arabization of medicine

encouraging students' attendance at lectures [14]. Since incompetent tutors were identified as a problem by so many students in the present study, exact reasons for this need to be studied further. Was this because their English was poor, they did not prepare their lectures, they do not know their subject or simply they do not know how to teach?

Nearly one-half of students translated most of the words in medical books into Arabic to facilitate studying. A glossary of translated terminology could be prepared and offered to students because almost $90 \%$ of staff members insisted that students should know the medical terminology in English. In other countries such as in Latin America, most of the leading US medical textbooks have been translated into Spanish and Portuguese [15]. There was a revival of Arabization in the beginning of the 19th century in Egypt. Following this, medical sciences were taught in Arabic for about 70 years and during this period about 72 textbooks were translated and many books were published [16].

The present study revealed that some students answered parts of written exams in Arabic although they should have answered only in English. This suggests that thinking, understanding and expressing using their mother tongue may be easier for some students. Previous studies have appreciated learning with the mother tongue for this reason $[5,6]$.

Many students (61.8\%) felt there was a gap between their medical studies and their clinical practice with patients and they attributed this to learning medicine in a foreign language. This should be investigated in further studies. Students requested that learning how to take a patient's history in clinical rounds should be in Arabic. Communication skills and health education were identified as aspects of medicine that might be taught in Arabic. Students need to understand the various Arabic colloquial dialects and idioms of patients who may come from different regions. Harmsen et al. recommended that medical students and physicians should be trained to become aware of patients' cultural backgrounds so as to bridge language barriers [17]. Books in the medical specialties that were suggested as suitable for Arabization should be available for students to use besides the English copies.

A previous study recommended that students at colleges of medicine, pharmacy, science and computer science be taught the Arabization process [18]. Students at those colleges must study the Arabic equivalents to English technical terms in their major area of specialization and it must be part of their course grades.

The choice of the language of medical teaching, whether English or Arabic, should not be considered as all-or-none. Previous studies highlighted that in undergraduate and postgraduate learning, students with the greatest need for language support should be properly helped [19,20].

Although about $40 \%$ of staff members were strongly against the idea of Arabizing medicine, $28.6 \%$ believed that lectures given in Arabic would be communicated more effectively to students and $40.7 \%$ of them expected that Arabization would result in a harmony between students' thinking and speaking. This shows that we need to use the Arabic language in medical education; but how, when and in what fields? This should be discussed by decision-makers in medical education.

Previous researchers have stated that it is far better for students to learn in their mother tongue as the time taken by students to understand information in English is about twice as long as it takes to understand it in Arabic, the mother tongue $[5,21]$. By contrast, in Gezira University in Sudan, an experiment with Arabization of medicine showed no difference between the performance of students learning medicine in Arabic and those learning it in English [22]. Other studies have also explored the effect on performance of teaching medical students in their mother tongue. In the United Arab Emirates, undergraduate students performed better in communication skills using their mother tongue (Arabic) than in English [23]. Other studies have also found that language barriers add new anxieties and worries for health professionals in their dealing with patients with a different language [24,25]. 
In Saudi Arabia, a study showed a positive attitude towards teaching medicine in Arabic by students, and that Arabization was welcomed provided it was approached gradually and with adequate planning [26]. One of the reasons behind the resistance of medical staff towards Arabization in the current study was the fear that it would have a negative impact on the student's education level. Medical professionals need continuing professional development to keep up-to-date and many of the resources for this are in English. The possibility that students who learn medicine in Arabic will not be competent enough in English to be able to use English scientific resources efficiently has been previously stated [6].
Currently, several activities concerning the Arabization of health sciences are being implemented by the Arabization of Health Sciences Network in collaboration with the World Health Organization Regional Office for the Eastern Mediterranean. These include training courses for translators, editors and publishers and production of educational materials in health subjects [27].

Though the official language in university textbooks and in examinations in the faculty of medicine is currently the English language, however, the actual language used by faculty members in delivering the lectures and in Oral exams is a combination of Arabic and English language. In addition, the actual language used in patient communication is Arabic (the mother tongue) though the teaching is in English. In the clinical rounds students use the Arabic language in elaborating the complaints of patients, in explaining the condition the patient has, and in prescribing the medications he needs.

Most of the official reports offered by the hospital are also in Arabic language so we are facing a situation where we teach in a language and we practise in a different language.

Although this study was exploratory, it demonstrates that the idea of teaching some medical courses in Arabic is not out of the question and that teaching interventions are necessary for students whose English language is not adequate. Further studies would help us to explore this in more detail

\section{References}

1. Drouin J. Educating future physicians for a minority population: a French-language stream at the University of Ottawa. Academic Medicine, 2002, 77(3):217-221

2. Haidinger G, Frischenschlager O, Mitterauer L. Reliability of predictors of study success in medicine. Wiener Medizinische Wochenschrift, 2006, 156(13-14):416-420.

3. Khayat MH. التعريب: حديث مستطرد [Arabization: A continuous conversation]. Medical Arabization, 2002, 6(1):62-67.

4. Dewedar A. Dعريب التعليم العالى في الوطن العربى. ضرورته معوقاته, شروط Arabization of higher education in the Arab world. Necessity, obstacles, conditions and requirements of

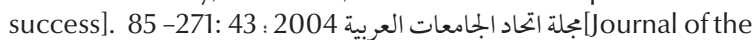
Association of Arab Universities, 2004, 43:271-285].

5. Al-Kateb B, Review of the history of the teaching of medicine in Arabic. Eastern Mediterranean Health Journal, 1999, 5(3):597-603.

6. Ali EA. The language of scientific research. IslamOnline [online article] (http://www.islamonline.net/servlet/Satellite?c= Article_C\&cid=1158658285017\&pagename=Zone-EnglishHealthScience\%2FHSELayout, accessed 29 June 2010).

7. Maher J. The development of English as an international language of medicine. Applied Linguistics, 1986, 7(2):206-218.

8. Kassem AM. Learning English makes sense. Student British Medical Journal, 2004, 12:133-176.

9. El-Awady NA. Arabized medicine moves one step forward. IslamOnline [online article] (http://www.islam-online.net/English/ Science/2005/04/article06.shtml, accessed 29 June 2010).

10. Manzar S. The English language and Arabic medical students. Medical Education, 1999, 33(5):394-395.

11. Conaboy KA et al. Central Asian Republics: a case study for medical education reform. Journal of Continuing Education in the Health Professions, 2005, 25(1):52-64.

12. Weber A et al. Ausbildungs- und Berufserwartungen der Arztegeneration von morgen [Educational and occupational expectations of tomorrow's generation of physicians]. Gesundheitswesen, 1996, 58(12):629-634.

13. Fido A, Al-Kazemi R. Effective method of teaching psychiatry to undergraduate medical students: the student perspective. Medical Principles and Practice, 2000, 9:255-259.

14. Milaat WA, El-Gamal FM Factors affecting the use and attitude towards medical resources and educational methods in a Saudi medical school. Annals of Saudi Medicine, 1994, 14(3):209-214.

15. Sung JY et al. Textbook of clinical medicine for Asia. Hong Kong, Chinese University Press, 1998.

16. Malak A. تعريب التعليم العالى:تنمية لغوية و ثقافية [Arabization of higher education: linguistic and cultural development]. Medical Arabization, 1993, 5(June).

17. Harmsen JA et al. Patients' evaluation of quality of care in general practice: What are the cultural and linguistic barriers? Patient Education and Counselling, 2008, 72(1):155-162.

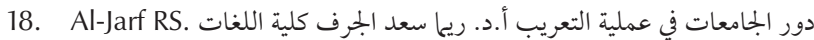

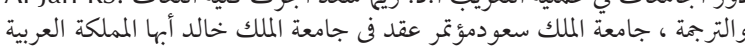
Role of universities in the process of Arabization. Faculty of Languages and Translation, King Saud University. A conference held in King Khalid University, Abha, Saudi Arabia]. (http://faculty.ksu.edu.sa/aljarf/default.aspx, accessed 1 July 2010).

19. Letelier LM et al. Exploring language barriers to evidencebased health care (EBHC) in post-graduate medical students: a randomised trial. Education for Health (Abingdon, England), 2007, 20(3):82.

20. Chur-Hansen A. Language background, proficiency in English, and selection for language development. Medical Education, 1997, 31 (5):312-319.

21. Al-Ahmad N. من تجارب التعريب في بعض الجامعات العربية[From the ex-

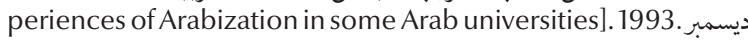
- " Journal of Arabization, 1993, Dece . ber, No. 6]. 
22. Mahmadani AA, Abdel Rahman SH. تقييم أثر التعريب على تحصيل طلاب الطبا جامعة الجزيرة السودان المجلة المبلة الصحية لشرق المتوسط منظمة الصحة

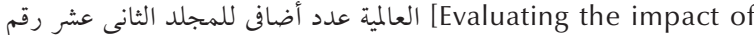
Arabization on medical students' acquisition, Gezira University, Sudan]. Eastern Mediterranean Health Journal, 2006, 12(S2):S223-229.

23. Swadi $H$ The impact of primary language on the performance of medical undergraduates in communication skills. Medical Teacher, 1997, 19(4):270-274.

24. Al-Naseri H. Found in translation. Student BMJ, 2005, 13:133176.
25. Al-Shahadat S. لغة التواصل بين الطبي و المريض العربى [Language of communication between Arab doctor and patient]. Medical Arabization, 2008, 12(2):87-89.

26. Albar AA, Assuhaimi SA. Attitude of medical students and postgraduate residents at King Faisal University towards teaching medicine in Arabic. Saudi Medical Journal, 1996, 17(2):230234.

27. Sara K. Arabization of Health Sciences Network (AHSN): current issues, problems, trends and the role of the Regional Office. Saudi Medical Journal, 2004, 25(1):S47.

\section{Essential health technologies}

Health technologies are developed to solve a health problem and improve quality of lives. They form an indispensable component of the services health systems can offer in the prevention, diagnosis and treatment of disease and in alleviating disability and functional deficiency. Access, including in primary health care, to safe and effective health technologies relies on policies for selection and management based on scientific evidence and best practice for organization of their management and use.

Further information on technical areas such as blood transfusion safety, diagnostic imaging, transplantation and medical devices can be accessed at: http://www.who.int/eht/en/ 